\title{
Post-traumatic Stress Disorder Related to Trait Emotional Intelligence of Slovaks in Comparison to Turkish Immigrants in Slovakia
}

\author{
Lada Kaliska $^{1,1}$, Bilal Akbey ${ }^{2}$ \\ ${ }^{1}$ Department of Psychology, Faculty of Education, Matej Bel University in Banska Bystrica, Slovakia \\ ${ }^{2}$ Faculty of Psychology, PanEuropean University in Bratislava, Slovakia
}

\begin{abstract}
Objective: The study aim was to investigate the differences and prediction of post-traumatic stress disorder (further PTSD) by trait emotional intelligence (further EI) and its four factors (well-being, self-control, sociability, and emotionality) of two specific groups. Method: Research groups were immigrants coming to Slovakia from Turkey $\left(\mathrm{N}=104, \mathrm{M}_{\mathrm{age}}=35.4\right.$ years, $/ \mathrm{SD}=10.2 /)$ and national majority of the Slovaks living in Slovakia $(\mathrm{N}=264$, $\mathrm{M}_{\mathrm{age}}=33.2$ years $/ \mathrm{SD}=11.9 /$ ). PTSD was assessed by PCL-5 (PTSD Checklist for DSM-5, Weathers et al., 2013), and trait EI by Trait Emotional Intelligence Questionnaire-Short Form (TEIQue-SF; Petrides 2009) modified and adapted to Turkish and Slovak population. Results: T-test analysis and effect size estimation proved a higher level of PTSD for Turks in comparison to the locals $(\mathrm{p} \leq .001 ; \mathrm{d}=.54)$, though no differences were proved in trait EI and its four factors. Correlation and regression analysis revealed the higher level of trait EI is significantly related to lower level of PTSD (strong relations for the immigrants). Global trait EI level predicts significantly to a certain extent PTSD in both groups (for the Turks 54\%, F $(1,103)=119.627, \mathrm{p} \leq .001$ ), for the Slovaks $16 \%, F(1,263)=50.526, p \leq .001)$. Self-control was the only significant moderate predictor in both groups $(\mathrm{p} \leq .001)$ whilst controlling for the other EI factors. Conclusions: The study emphasizes the need to educate, facilitate and support any man's emotion-related personality traits, especially self-control skills, as a form of PTSD prevention.

Keywords: immigrants, mental health, post-traumatic stress disorder, trait emotional intelligence, Turks in Slovakia.
\end{abstract}

\section{Clinical Impact Statement}

The main purpose of the study was to find out about the level of post-traumatic stress disorder (further on PTSD) of immigrants from Turkey living in Slovakia in comparison to the local ones. The second aim was to investigate emotion-related personality traits (covered in trait emotional intelligence concept) as a potential predictor and form of prevention to PTSD. The results proved a higher level of PTSD for immigrants living in Slovakia, though there were no differences in their emotion-related traits, i.e. in EI factors: well-being, selfcontrol, emotionality, sociability and in the global level of trait emotional intelligence in comparison to the local ones. One of the key factors helping to deal with PTSD seems to be covered in the self-control factor of emotional intelligence. The study draws the attention of experts to strengthen the personality, especially the selfcontrol skills, of any being, enabling him/her to deal more effectively with experienced traumas, thus increasing their mental health.

\section{Introduction}

One of the current and most serious topics discussed around the world (American Psychological Association, 2019), not excluding the European Union (Migration policy in the strategic agenda 2019-2024 included in A new strategic agenda 2019-2024, EU, 2019), and within it, Slovakia (Migration Policy in Slovakia, 2011), is the issue of migration policy. Migration is defined as a process of relocating, either across an international border, or within any states including refugees, displaced persons, uprooted people, and economic migrants (IOM SR, 2018; Perruchoud, 2004). The increasing number of immigrants coming from eastern and southern countries into Europe influences social science research to investigate their mental health to provide appropriate interventions.

\footnotetext{
${ }^{1}$ Correspondent e-mail: lada.kaliska@umb.sk
} 
The International Organization for Migration in the Slovak Republic (IOM SR, 2018) states that currently, every $7^{\text {th }}$ person in the world is a migrant and the most attractive destination is Europe. The data from 2014 indicate that migrants account for $7 \%$ of the total population of the EU states and the largest proportion of third country migrants are citizens from Turkey (1.63 million in IOM, 2018). In 2017, the EU recorded the second-highest increase (by 59\%) of asylum applications from citizens from Turkey (Eurostat, 2017a, 2017b). The current situation in Turkey testifies to no expected decrease. The lives of Turks are at constant risk from natural disasters and socio-political circumstances.

There needs to be acknowledged that the situation in Slovakia as one of the EU members is different. Slovakia is still not one of the final destinations of the current migratory waves. However, there is also a certain increase of immigrants (the number increased six times from 2004 to 2018, in IOM, 2018) influenced by joining the EU and the Schengen Agreement. Today, they represent 2.2\% of the total population in Slovakia (IOM, 2018). At present, Slovakia officially registers 84 Turks living in Slovakia (IOM, 2018). On the other hand, the Turkish Embassy in Slovakia records about 1050 Turks coming from Macedonia and 351 Turks coming directly from Turkey. This discrepancy between official statistics and data from the embassy arises because the Office of Labour, Social Affairs and Family in Slovakia (2018) collects data on valid employment permits, but they do not capture the whole economic activity of foreigners since only some categories of foreigners are required to obtain work permits. Overall, there are no data on the structure of foreigners in Slovakia in terms of their education, economic activity, marital status, etc. (Blažek, Andrášová, \& Paulenová, 2013, p. 17), and as well, no statistics or research about their mental health.

\section{Post-traumatic Stress Disorder}

The migration process induces several stressful life events increasing the risk of mental health problems. Immigrants are subjected to exposure to stressful and traumatizing experiences (Shiroma \& Alarcon, 2011) related to acculturative stress and adaptation process. Haller, Cramer, Lauche, and Dobos (2015) indicated somatization, including post-traumatic stress disorder (PTSD), in diverse ethnic immigrant groups growing all over the world. The systematic review and a meta-analytical study done by Lanzara, Scipioni, and Conti (2019) reviewing 42 papers published between 2000 and 2017 with 38 cross-sectional analyses disclosed the prevalence and correlates of somatization (including PTSD) across the immigrant groups, depending on cultural variation, in reasons for migration, stress exposure, explanatory models of illness, coping, and other individual variables.

We presuppose the Turkish immigrants were subjected to strong traumatic experiences in their homeland, and also due to the adaptation process in a host country, they exhibit a higher level of somatic illness, especially post-traumatic stress disorder symptoms (further on PTSD) belonging to the anxiety disorders category (in ICD-10 named MKCh-10-SK as F43.1, 2017). PTSD arises as a reaction to an emotionally difficult and stressful intensive event, which, in its severity, exceeds the usual human experience and is traumatic for most people (Hašto, Švančarová, Suško, \& Gyén 2011). DSM-5 (APA, 2013) defines this syndrome as a mental illness arising from sudden, life-threatening, or personal integrity threatening events. An individual suffering from PTSD repeatedly experiences this event or events in his/her thoughts, dreams and fantasies, avoiding places, people, situations where the event/trauma originated. Traumatic events differ in frequency, intensity, and duration. We can classify them as one-time traumas (e.g., rape, assault, accident, the testimony of close human death, etc.) and persistent and long-lasting traumas (e.g., domestic violence, sexual abuse, etc.).

PTSD symptoms in MKCh-10-SK (2017) and DSM-5 (2013) are generally grouped into four types: intrusive memories, avoidance, negative changes in thinking and mood, and changes in physical and emotional reactions. They usually include, e.g., inability to process, in part or in full, important moments from a traumatic event, increased mental sensitivity and excitability, sleeping disorders, upsetting dreams or nightmares, irritability or flushing of anger, concentration difficulty, hopelessness or memory problems, inability to experience positive emotions ending in self-destructive behavior. Most of these symptoms are being covered and assessed by the Posttraumatic Stress Disorder Checklist for DSM-5 (PCL-5) produced by Weathers et al. (2013).

It has been proved that only a small minority of people in the population develop PTSD (Atwoli, Stein, Koenen, \& McLaughlin 2015), even though many of them are exposed to traumas at some point in their life (Benjet et al. 2016), opening up the question of its determination. We presuppose trauma exposure is common throughout the whole world, unequally distributed, and differential across trauma types concerning PTSD risk (Kessler et al., 2017). In the meta-analytical study of 42 research papers, in only four of them was somatization found to be significantly prevalent in immigrants relative to the country's natives (Lanzara et al., 2019). Referring to Turkish population, only a few studies proved psychosomatic prevalence versus the locals. It has been proved in research that the Turkish immigrants, especially Turkish women, living in various countries (e.g. Australia, Germany, Netherlands, Belgium, Sweden etc.) had higher prevalence of somatic symptoms, psychological distress, depression, and sever level of somatization (Lanzara et al., 2019).

Hašto et al. (2011) pointed to the fact that we lack research data on PTSD in countries where ethnic variation, civil wars, political unrest, or terrorist attacks are taking place, including also Slovakia. Therefore, a question about individual personality differences in psychological vulnerability to PTSD opens up. One prior consideration is that PTSD risk varies significantly by trauma type and that another fact not being considered in 
such studies, can be personality factors such as hardiness, or socio-economical factors, social support, cultural, organizational and certain event determination (Vymětal, 2009). The traumatic experience is filtered through cognitive and emotional processes before it can be appraised as an extreme threat. Because of individual differences in this appraisal process, different people appear to have different trauma thresholds; some might be more protected from and some more vulnerable to developing clinical symptoms after exposure to extremely stressful situations opening up a question of emotion-related factors influencing PTSD.

\section{Trait Emotional Intelligence}

Individuals with PTSD show a certain degree of vulnerability towards personality and emotionality predispositions. The increased level of emotionality, anxiety and depression, concentration, memory and sleep disorders, loss of self-control, negative thinking and moods, destructive behavior are being determined by low self-esteem (Práško, Hájek, \& Preiss, 2002), by an inability to control and overcome the traumatic experience and related emotional processing and adjustment to it, as well as by lack of social and emotional support. It is plausible that appraisals of emotional and physiological responses during the event could be influenced by how well they are identified and understood, affecting the degree of arousal and remaining resources available to encode and process emotionally overloaded memories. These findings have been proved with the individuals (Malaysia adolescents) suffering from severe PTSD symptoms who lacked the ability to understand and use emotions (Ersoy \& Uysal, 2018; Ghazali, 2014) as emotion-related personality factors covered in the trait emotional intelligence concept (further on EI).

The trait EI is explained as a constellation of self-capacities and emotional behavioral responses that bring together qualitatively different styles of behavior and experiences related to emotion processing (Petrides, Pita, \& Kokkinaki, 2007), being also called emotional self-efficacy. Trait EI represents emotion recognition, self-perception and personality dispositions. The model comprises of 15 facets loading on 4 factors and global trait EI. The emotionality factor reflects the perception and expression of emotions (including trait empathy, emotion perception, emotion expression and relationship skills) and a high level suggests the ability to perceive, mirror and share one's own and others' emotions, relationships with others, influencing emotional well-being, productivity and ability to listen to others. The self-control factor covers tendencies to control the emotions and impulses (in emotion regulation, (low) impulsiveness, stress management) where a healthy level of self-control, low level of impulsiveness and use of effective coping strategies represent a potential for combating negative emotions (emotional seizure, psychic instability, and depression). The sociability factor reflects the own inner affectivity in interpersonal relations while controlling and regulating the emotions (including assertiveness, social relationships, and social competence) pointing at the ability to move in social interactions without difficulties. The last factor of well-being includes the facets of trait optimism, trait happiness, and self-esteem. Its high level indicates subjective satisfaction and a feeling of happiness, positive view of life, and inner fulfillment. More details about the four factors can be found in Petrides (2009), Petrides et al. (2007) and Kaliská and Nábělková (2015).

\section{PTSD and trait EI}

We assume that a higher degree of emotional personality disposition in the sense of Petrides ${ }^{\prime}$ trait EI model will be in a negative relation to the symptoms of PTSD. Our assumptions cannot be supported by local studies because the relation of the studied variables has not been analyzed in our cultural setting nor with the specific research sample of immigrants, the Turks living in Slovakia. Our research assumption was based only on foreign studies, where Hall-Clark et al. (2017) have proved ethnoracial differences (effect sizes in the small to medium range) of Hispanic/Latino and African American in favor to lower scores in global level of PTSD and its five symptoms by the PTSD Checklist-Stressor-Specific Version (PCL-S) for White participant service member males. Martskvishvili (2015) demonstrated a $2.9 \%$ rate of variability being predicted by global trait EI level of PTSD symptoms, especially in self-control and emotionality, being in a significant negative relation to PTSD symptoms in a sample of 200 American individuals (Mage=38.15, SD=14.7). EI assessed by Schutte's Scale of trait EI was also in a negative relation to PTSD $\left(r=-.44^{* *}\right)$ in a random sample of 200 Indian men (age range 20-35 years) conducted by Vinayak, Safariolyaei, and Pragu (2016). These findings are supported by Hunt and Evans (2004 by Stough, Saklofske, and Parker (2009), who investigated that individuals with a higher EI showed a lower level of PTSD symptoms

\section{The research aim and research hypotheses}

The main research aim was to find out about the post-traumatic stress disorder and trait EI differences between our two research groups of interest and investigate possible trait EI and its four factors prediction of PTSD level for each research group.

Based on the literature review, we have stated the following three research hypotheses (RH) and two research questions (RQ): 
RH1: We presuppose the Turks from Slovakia have a higher level of PTSD symptoms than the Slovaks from Slovakia.

RH2: We presuppose the Turks from Slovakia have a lower level of global trait EI level and its four factors than the Slovaks from Slovakia.

RH3: We presuppose the factors and global trait EI levels are negatively related to PTSD in both groups.

RQ1: Is it possible to predict the global level of PTSD by the global trait EI level in the two research groups and to what extent?

RQ2: Which factor of trait EI predicts the global level of PTSD in two research groups?

\section{Method}

\section{Research groups}

Our research aim was based on two independent research groups, i.e., the Turks living in Slovakia and the Slovaks living in Slovakia.

The first research group was carried out by convenient, occasional, and deliberate sampling during Friday prayer at the largest mosque in Slovakia in Levice in November 2017. Overall, we addressed 158 Turks and Macedonian Turks living in Slovakia, but we could only include 104 fully completed questionnaires in our analysis (66\% return on questionnaires). In this sample, there were $32 \%$ of Turks and $68 \%$ of Macedonian Turks living in Slovakia aged between 19 and 56 (Mage=35.4 years, /SD=10.2/).

The second research group consisted of the Slovaks (also of nationality Slovak) living in Slovakia. It was carried out by convenient sampling and also by the online research data collection. The Slovak research sample consisted of 264 individuals aged between 18 and 72 (Mage=33.2 years $/ \mathrm{SD}=11.9 /)$.

\section{Research methods}

PCL-5 (PTSD Checklist for DSM-5) was created by Weathers et al. (2013) at the National Center for the Treatment and Research of PTSD in the United States (www.ptsd.va.gov), respecting the latest $5^{\text {th }}$ version of the Diagnostic and Statistical Manual of Psychiatric Diseases (DSM-5, 2013). PCL-5 is a 20-item questionnaire aimed at assessing PTSD symptoms by the DSM-5 classification. It is used to assess the DSM-5 symptoms of PTSD using a five-point Likert scale ranging from 0 (not at all) to 4 (extremely). Participants indicated the extent to which they had been bothered by each symptom in the past month. It allows the screening of PTSD symptoms in an individual or a group as a part of the preliminary diagnosis of PTSD symptoms. The scale can also be used for research purposes. The administration lasts 5-10 minutes. Considering reliability in terms of internal consistency (Cronbach's alpha for the whole tool: for the Turks: $a=0.92 / 0.90$ for females, 0.92 for males/) and for the Slovaks: $a=0.90 / 0.90$ for females, 0.91 for males/) achieves highly acceptable values in both research groups. PCL-5 was administered in the mother tongue of both samples.

Trait EI was assessed by the Turkish version of TEIQue-SF (Trait Emotional Intelligence Questionnaire-Short Form) adapted and verified by Ulutas (2017) in Turkey and is available in the web-page of the questionnaire author, Petrides (2009) (www.psychometriclab.com). The short Slovak version of the TEIQueSF (Trait Emotional Intelligence Questionnaire-Short Form) was adapted to the Slovak conditions and verified by Kaliská, Nábělková, and Salbot (2015). The international studies, including the Turkish and Slovak versions, confirm a four-factor structure comparable to the original one, and also satisfactory reliability and validity (construct /convergent and discriminant/, incremental, criterion) of the TEIQue long and short forms also in Turkey (Deniz, Ozer, \& Isik, 2013; Ulutas, 2017) and in Slovakia (e.g. Kaliská, Nábělková, \& Salbot, 2015; Nábělková, 2012). TEIQue-SF is designed to measure the global trait EI level (four factors only for research purposes) from the age of 18. The instrument consists of 30 items answered by a seven-point Likert scale (1 completely disagree to 7 - completely agree). The administration takes 5-7 minutes. Reliability estimate in the sense of inner consistency (Cronbach's alpha for the whole tool: for the Turks: $a=0.97 / 0.98$ for females, 0.97 for males/; for the Slovaks: $a=0.89 / 0.94$ for females, 0.90 for males/) reaches highly acceptable values for both research samples. It was administered in the mother tongue of the respondents.

\section{Results}

The normal distribution of the variables measured by the TEIQue-SF and PCL-5 questionnaires was based on the descriptive characteristics of the normality distribution shape (coefficients of skewness and kurtosis) where West and Finch (1996, in Cooper \& Petrides 2010) claimed that skewness and kurtosis in absolute values 0-2 and 0-7 are considered as values demonstrating univariate normality. We state that the variables we have monitored have a normal distribution, so we used parametric tests for further analyses. 


\section{Cross-cultural comparison of PTSD level}

RH1: We presuppose the Turks from Slovakia have a higher level of PTSD symptoms than the Slovaks from Slovakia.

Our first intention was to find out about PTSD level differences in two research groups of different cultural origin through the PCL-5 checklist, as presented in Table 1.

Table 1.

The PTSD Cross-cultural Differences

\begin{tabular}{lcccccccc}
\hline & Min & Max & Mean & $\begin{array}{l}\text { Standard } \\
\text { deviation }\end{array}$ & Median & t-test & $95 \%$ CI & d-index \\
\hline $\begin{array}{l}\text { Turks from Slovakia } \\
\text { (N=104) }\end{array}$ & 14.0 & 70.0 & 33.24 & 12.14 & 30.0 & & {$[30.88$,} & \\
$\begin{array}{l}\text { Slovaks from Slovakia } \\
\text { (N=264) }\end{array}$ & 1.00 & 63.0 & 26.43 & 13.16 & 25.0 & $4.72^{* * *}$ & $\begin{array}{l}35.60] \\
{[24.82,}\end{array}$ & .54 \\
\hline
\end{tabular}

${ }^{* * * *} \mathrm{p} \leq .001$ Min - minimum, Max - maximum, CI - Confidence Interval.

Parametric t-test analysis points to highly significant differences in the PTSD level in favor of the Slovaks. Besides standard statistical analysis, we have also focused on the so-called practical (or clinical) significance of differences (Hendl, 2009) based on Cohen's effect-size indicator (1988), which is independent of the sample size. Cohen (1988) has determined conventional values that simplify the decision when we can talk about large $(\mathrm{d} \geq .80)$, medium $(.80 \geq .50)$ or little effect $(\mathrm{d}<.50)$. We can confirm our hypothesis $(\mathrm{H} 1)$ because the PTSD was significantly higher in the Turks from Slovakia than the Slovaks $(\mathrm{p} \leq .001 ; \mathrm{d}=.54)$ at a medium effect size.

\section{Cross-cultural comparison of trait EI and its four factors}

RH2: We presuppose the Turks from Slovakia have a lower level of global trait EI level and its four factors than the Slovaks from Slovakia.

Another research aim was concentrating on the investigation of cross-cultural trait EI and its factors level differences between the research groups of various cultural and social background measured by the TEIQue-SF presented in Table 2.

\section{Table 2.}

Basic Descriptive Indicators and the Cross-cultural Difference Estimation of the Global Trait EI and its Factors Assessed by the TEIQue-SF Questionnaire between Two Research Groups

\begin{tabular}{|c|c|c|c|c|c|c|c|c|c|}
\hline \multicolumn{2}{|c|}{$\begin{array}{c}\text { Trait EI } \\
\text { (TEIQue-SF) }\end{array}$} & Min & Max & Mean & $\begin{array}{l}\text { Standard } \\
\text { deviation }\end{array}$ & Median & $95 \%$ CI & $\begin{array}{l}\text { t- } \\
\text { test }\end{array}$ & $\begin{array}{c}\mathrm{d}- \\
\text { index }\end{array}$ \\
\hline \multirow{5}{*}{ 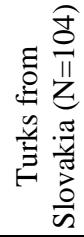 } & Well-being & 1.67 & 7.00 & 5.59 & 1.35 & 6.33 & {$[5.33,5.85]$} & -.00 & .00 \\
\hline & Self-control & 1.83 & 6.67 & 5.00 & 1.17 & 5.42 & {$[4.77,5.23]$} & 1.69 & .21 \\
\hline & Emotionality & 2.13 & 7.00 & 5.26 & 1.28 & 5.75 & {$[5.01,5.51]$} & -.68 & .09 \\
\hline & Sociability & 1.67 & 7.00 & 4.92 & 1.34 & 5.33 & {$[4.66,5.18]$} & 1.83 & .22 \\
\hline & Global EI & 1.90 & 6.80 & 5.20 & 1.25 & 5.70 & {$[4.96,5.44]$} & .69 & .09 \\
\hline \multirow{5}{*}{ 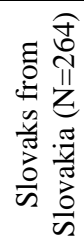 } & Well-being & 2.00 & 7.00 & 5.59 & 1.03 & 5.83 & {$[5.47,5.72]$} & & \\
\hline & Self-control & 1.50 & 6.67 & 4.78 & .94 & 4.83 & {$[4.66,4.89]$} & & \\
\hline & Emotionality & 2.25 & 7.00 & 5.36 & .90 & 5.38 & {$[5.25,5.46]$} & & \\
\hline & Sociability & 1.67 & 7.00 & 4.66 & .95 & 4.83 & {$[4.54,4.77]$} & & \\
\hline & Global EI & 2.50 & 6.70 & 5.11 & .75 & 5.20 & {$[5.02,5.20]$} & & \\
\hline
\end{tabular}

Note: Min - minimum, Max - maximum, CI - Confidence Interval,

We can conclude there were neither significant differences estimated by t-test analysis nor effect size differences in trait EI global level and its four factors between the Turks living in Slovakia and the Slovaks. We have to deny the hypothesis $\mathrm{H} 2$. 


\section{Relation and prediction of PTSD by trait EI}

RH3: We presuppose the factors and global trait EI levels are negatively related to PTSD syndrome in both groups.

Our last research aim was to analyze the potential relation and also prediction of PTSD assessed by PCL-5 by the level of trait EI and its four factors assessed by TEIQue-SF independently for each research group. The correlation coefficients explored by Pearson correlation analysis are presented in table 3.

Table 3.

Correlation of Global Trait EI and its Factors with the Global Level of PTSD in a Research Sample of the Turks from Slovakia and the Slovaks from Slovakia

\begin{tabular}{ll|l}
\hline $\begin{array}{l}\text { Trait EI } \\
\text { (TEIQue-SF) }\end{array}$ & $\begin{array}{c}\text { Turks from } \\
\text { Slovakia (N=104) } \\
\text { PTSD (PCL-5) }\end{array}$ & $\begin{array}{c}\text { Slovaks from Slovakia } \\
(\mathrm{N}=264)\end{array}$ \\
\hline Well-being & $-.705^{* * *}$ & $-.333^{* * *}$ \\
Self-control & $-.754^{* * *}$ & $-.474^{* * *}$ \\
Emotionality & $-.710^{* * *}$ & $-.206^{* * *}$ \\
Sociability & $-.681^{* * *}$ & $-.230^{* * *}$ \\
Global trait EI & $-.735^{* * *}$ & $-.405^{* * *}$ \\
\hline \multicolumn{2}{c}{${ }^{* * *} \mathrm{p} \leq .001$} \\
\hline
\end{tabular}

We note that all of the studied variables enter into weak to strong highly significant negative relations with the overall level of PTSD symptoms, pointing to the fact that the correlations are the strongest for all four factors and global level of trait EI for the Turks living in Slovakia. By our statistical analysis, the research hypothesis RH3 can be supported.

The next two research questions were aimed at estimating the prediction of the global level of PTSD by the global trait EI level and concretely by its four factors in two research groups separately by means of regression analysis. At first, we entered a variable of global PTSD level measured by the PCL-5 scale as the dependent variable and independent variable was global trait EI level assessed by the TEIQue-SF presented in Table 4 and then we were interested in which of the trait EI factors may predict the global PTSD level significantly while controlling for the other factors, and the results are presented in Table 5.

Table 4.

Regression Analysis of Trait EI Level for the Dependent Variable of Global PTSD Level for the Turks from Slovakia and the Slovaks from Slovakia

\begin{tabular}{|c|c|c|c|c|c|c|c|c|c|}
\hline Research group & Model & $\mathrm{R}$ & $\mathrm{R}^{2}$ & $R_{a d j}^{2}$ & $\mathrm{~F}$ & $\mathrm{P}$ & $\begin{array}{c}\text { Beta- } \\
\text { coeffic. }\end{array}$ & $\mathrm{t}$ & $\mathrm{p}$ \\
\hline $\begin{array}{l}\text { Turks from } \\
\text { Slovakia } \\
(\mathrm{N}=104)\end{array}$ & 1 & .735 & .540 & .535 & 119.63 & .000 & -.735 & -10.94 & .000 \\
\hline $\begin{array}{l}\text { Slovaks from } \\
\text { Slovakia }\end{array}$ & 1 & .405 & .164 & .161 & 50.53 & .000 & -.405 & -7.11 & .000 \\
\hline
\end{tabular}

Note: $\mathrm{R}=$ coefficient of multiple correlation, $\mathrm{F}=$ value for whole $\mathrm{F}$-test, $\mathrm{R}^{2}=$ determination index, $\mathrm{p}=$ significance for the whole F-test, $\mathrm{R}^{2}$ adj. = adjusted index determination.

We have confirmed that the global trait EI level assessed by TEIQue-SF predicts significantly, to a certain extent post-traumatic stress disorder in both samples. The level of variation differs in every group. In the Turkish group, global trait EI can explain 54\% proportion of variance of the global PTSD measured by the PCL5 scales $(\mathrm{F}(1,103)=119.627, \mathrm{p} \leq .001)$, while just $16 \%$ of the PTSD variance can be explained by the global trait EI level in a sample of the Slovaks $(\mathrm{F}(1,263)=50.526, \mathrm{p} \leq .001)$. The adjusted prediction correction index and the determination index size did not significantly reduce the predictable variability in the global PTSD level in all groups.

\section{Table 5.}

Trait EI Factors Regression Coefficients Estimate for the Dependent Variable of Global PTSD Level in the Turks from Slovakia and the Slovaks from Slovakia 


\begin{tabular}{|c|c|c|c|c|c|c|c|c|c|}
\hline \multirow{2}{*}{\multicolumn{2}{|c|}{ Model PTSP }} & \multicolumn{4}{|c|}{$\begin{array}{c}\text { Turks from Slovakia } \\
(\mathrm{N}=104)\end{array}$} & \multicolumn{4}{|c|}{$\begin{array}{c}\text { Slovaks from Slovakia } \\
(\mathrm{N}=264)\end{array}$} \\
\hline & & \multirow[t]{2}{*}{$\begin{array}{l}\text { Beta- } \\
\text { coef. }\end{array}$} & \multirow{2}{*}{$\begin{array}{c}\mathbf{t} \\
20.41\end{array}$} & \multirow{2}{*}{$\begin{array}{c}\mathbf{p} \\
.000\end{array}$} & \multirow[t]{2}{*}{$\begin{array}{l}\text { Par. } \\
\text { corr. }\end{array}$} & \multirow[t]{2}{*}{$\begin{array}{l}\text { Beta- } \\
\text { coef. }\end{array}$} & \multirow{2}{*}{$\begin{array}{c}\mathbf{T} \\
12.30\end{array}$} & \multirow{2}{*}{$\begin{array}{c}\mathbf{p} \\
.000\end{array}$} & \multirow[t]{2}{*}{$\begin{array}{l}\text { Par. } \\
\text { corr. }\end{array}$} \\
\hline 1 & (constant) & & & & & & & & \\
\hline & Well-being & .09 & .42 & .676 & .04 & -.14 & -1.91 & .057 & -.12 \\
\hline & Self-control & -.66 & -3.43 & .000 &.$- .33^{* * * *}$ & -.41 & -6.37 & .000 & $-.37^{* * * *}$ \\
\hline & Emotionality & -.20 & -1.09 & .277 & -.11 & .03 & .369 & .713 & .02 \\
\hline & Sociability & .00 & .03 & .980 & .00 & -.00 & -.011 & .992 & -.00 \\
\hline
\end{tabular}

By means of regression analysis, entering trait EI factors (well-being, self-control, emotionality, and sociability) as the independent variables, we found that the only factor that significantly predicts the global PTSD level is the self-control factor at the significance level of $\mathrm{p} \leq .001$ in both research groups. We also point to the fact that in these research groups, whilst controlling for other trait EI factors, only this factor stays in a moderate negative significant relation to a global level of PTSD syndrome.

\section{Discussion}

PTSD was included in the $3^{\text {rd }}$ edition of DSM-III classification by the American Psychiatric Association (APA) for the first time in 1980. Since then, it has filled an important gap in psychiatric theory and practice (Friedman, 2013), though it also has become an important and interesting topic for research itself. We can conclude according to the literature review, this topic has not been well investigated in the Slovak conditions and not at all with respect to certain special groups, e.g. immigrants in Slovakia. We refer with this study to criticism from the perspective of cross-cultural psychology and medical anthropology, especially with respect to refugees, asylum seekers, political torture victims and immigrants from non-Western regions, arguing that since PTSD has usually been diagnosed by clinicians from Western industrialized nations working with patients from a similar background, the diagnosis does not accurately reflect the clinical picture of traumatized individuals from nonWestern traditional societies and cultures (Friedman, 2018). It is clear and we do agree that PTSD is a valid diagnosis cross-culturally (Hinton \& Lewis-Fernandez, 2011) and that is why the substantial cross-cultural variation and PTSD expression may be different in different countries and cultural settings and needs to be verified in its whole complexity.

In our study, it became a subject within two different research samples - the Slovak citizens and immigrants in this country from Turkey in relation to emotion-related personality factors of trait emotional intelligence theory created by Petrides (2009).

As we have expected the immigrants reach significantly (and of a middle size effect practical difference) a higher level of PTSD symptoms because of evident explanations. First, they have migrated from an unstable naturally, economically and politically, country - Turkey; secondly, their adaptation in the host country meets various criteria of a stressful situation. Migration is associated with stressors related to the migratory experience and acculturation in the host country. Therefore, the prevalence of PTSD among migrants disclosed by Bustamante, Cerqueira, Leclerc, and Brietzke (2018) in their meta-analytical study is very high (47\%), especially among refugees, who experienced it at nearly twice the rate of migrant workers.

On the other side, our attention to PTSD was based on our professional and personal (the co-author is of Turkish origin) interest in finding personal resources to assist in overcoming any life trauma by building up confidence, self-trust and trust in others. One potential could be seen in the concept of trait EI. There are numerous studies supporting the importance of trait EI in the prevention, intervention and diagnostic psychological setting with respect to increasing mental health. Trait EI is related to measures of rumination, life satisfaction, depression, dysfunctional attitudes, and coping (Petrides et al., 2007); to depression, anxiety, and social support as well as future state affectivity and emotional reactivity in neutral and stressful situations (Mikolajczak, Luminet, Leroy, \& Roy, 2007) or to emotional stability, extraversion and conscientiousness, selfconfidence, positive emotional state of mind (Kaliská \& Sollarová, 2017), and negatively to trait anxiety, type Dpersonality, self-depreciation and negative emotional state of mind (Kaliská \& Sollarová, 2017; Nábelkova, 2012). The Turkish TEIQue-SF questionnaire verified by Ulutas (2017), Engin (2017) and Deniz et al. (2013) supports these assumptions.

We were expecting a higher level of PTSD for the Turks and a higher level of trait EI and its four factors for the Slovaks. However, our statistical analysis did not support our second assumption, so we had to deny our stated hypothesis. We anticipate that even a short-term stay in a safer country can lead to an increase in positive emotions in an immigrant's life. Referring to the trait EI concept we can predict an increase in personal well-being leads to arising of positive expectations for the future without real threat and fear (factor of well- 
being). Their increased willingness to express their own emotions and to perceive the emotions of others creates a potential to establish new relationships in the wider social environment (factor of emotionality and sociability) and an increase in self-control skills improves controlling of impulses and aspirations, and enables the regulation and management of stress levels (self-control factor). Research studies confirm that a higher degree of trait EI is related to the individual's life satisfaction (Palmer, Donaldson \& Stough, 2008; Salbot \& Slušná, 2015). As well, the happiness levels of migrants converge substantially towards the average happiness level in the host country, particularly in terms of life evaluations (CohenMiller et al, 2018; Helliwell, Layard, \& Sachs, 2018). Turks fleeing from their homeland leave their country because they are mostly persecuted, they are under social, natural, political or economic oppression and violence, even threatened by natural catastrophes that make it impossible to live a full-fledged life in their own country; they deserve to and need improved mental health. As it was expected and proved within other research studies (Martskvishvili, 2015; Stough et al., 2009; Vinayak et al., 2016), the global trait EI level and its factors are highly significantly negatively related to PTSD, and global EI level is a significant predictor of the PTSD in both research groups. The self-control factor remained significant also in Martskvishvili (2015, $\mathrm{r}=-.242^{* *}$ ) and Ghazali's (2014) study where Malaysian adolescents, suffering the most severe symptoms of PTSD showed a low degree of ability to understand and regulate their emotions and the emotions of others $\left(\mathrm{r}=-.32^{*}\right)$. However, the higher emotion-related personality traits, the lower level of PTSD symptoms that occur are especially true for our immigrant research group. It leads to the conclusion that the happier, more satisfied, more emotionality aware, the higher the emotional sensitivity, the ability to express and regulate the emotions and to regulate one's own emotional experiences in a new setting, the lower the possibility of PTSD symptoms appearing. The higher the level of predispositions of trait EI, especially of self-control skills, the higher the effect of possibly reducing the risk of the occurrence, the impact of manifestations of a traumatic event and ability to deal with it and to maintain mental and physical health.

Among the significant limits of the research carried out are mainly the sampling of the research samples themselves, no representative groups of people enabling us to generalize our research results, cultural and also language bias, and at the same time the absence of a deeper personality analysis, specification of the length and reasons for migration and of related experienced traumas of the respondents. Then the usage of self-report instruments interfering to minimize the desirability effect, lack of validation of the PCL-5 scale in both groups, the study design itself and the overall impact limitation determined by our regional/religion focus, populationspecific, and conducive to incremental findings. These limits create potential sources for future work based on multi-country analysis, and the usage of other research methods to guarantee the validity of our results.

\section{Conclusions and recommendations into practice}

The main purpose of the study arose from the personal experiences of the study co-author (B.A.) as well as from the findings of the IOM SR, the only official organization providing assistance to migrants. The IOM emphasizes that social prevention / intervention with migrants in Slovakia is totally absent (Blažek et al., 2013), and is not sufficiently provided world-wide (IOM, 2018). There is a great need to draw the attention of experts to strengthen the personality, especially self-control skills of migrants and also of local people, enabling them to deal more effectively with experienced traumas, thus increasing their mental health. A prevalence of PTSD was found varying across the immigrant groups, depending on cultural variation in reasons for migration, stress exposure, explanatory models of illness, coping, and other individual variables (Lanzara, Scipioni, \& Conti, 2019). Referring to basic literature, we do emphasize a great need for better access to healthcare services for migrants, making it culturally, economically and linguistically available. The main goal of professionals is to mitigate or eliminate the negative consequences for the physical, and especially psychological, state of a person and to promote their growth in terms of the support and development of mental health. Supporting and strengthening the ability to control and to understand one's own emotions and the emotions of others from a pragmatic point of view (contributing to a successful functioning in the social world), providing interventions (targeted intervention in the regulation of behavior of an individual due to their traumatic experience) and prevention of an individual's problems will improve the mental health of everyone, either fellow citizen or migrant, in any country.

\section{References}

American Psychiatric Association (APA). (2013). Diagnostic and Statistical Manual of Mental Disorders. Fifth Edition (DSM-5). APA: USA.

American Psychological Association (APA). (2019). APA Immigration and Refugee Policy Statement. 59 Retrieved from https://www.apa.org/about/policy/apa-immigration-policy.pdf

Atwoli, L., Stein, D. J., Koenen, K. C., \& McLaughlin, K. A. (2015). Epidemiology of posttraumatic stress disorder: Prevalence, correlates and consequences. Current Opinion in Psychiatry, 28(4), 307-11. doi:10.1097/YCO.0000000000000167 
Benjet, C., Bromet, E., Karam, E. G., Kessler, R. C., McLaughlin, K. A., Ruscio, A. M., ... Koenen, K. C. (2016). The epidemiology of traumatic event exposure worldwide: Results from the World Mental Health Survey Consortium. Psychological Medicine, 46(2), 327-43. doi:10.1017/S0033291715001981

Blažek, M., Andrášová, S., \& Paulenová, N. (2013). Skúsenosti migrantov a migrantiek na Slovensku s násilím. Bratislava: IOM, 2013.

Bustamante, L. H. U., Cerqueira, R. O., Leclerc, E., \& Brietzke, E. (2018). Stress, trauma, and posttraumatic stress disorder in migrants: A comprehensive review. Revista Brasileira de Psiquiatria, 2018, 40, 22025. doi:10.1590/1516-4446-2017-2290

Cohen, J. (1988). Statistical power analysis for the behavioral science (2nd ed.). Hillsdale, NJ: Erlbaum.

CohenMiller, A. S., Sagitova, R., Ogay, S., Tselenko, Y., Shakhmanova, A., \& Saburova, A. (2018). What is a Family-Friendly Campus? An Exploratory Study to Develop Student Research and Provide Practical Results. American Journal of Qualitative Research, 2(2), 103-119.

Cooper, A., \& Petrides, K. V. (2010). A psychometric analysis of the Trait Emotional Intelligence Questionnaire-Short Form (TEIQue-SF) using Item Respond Theory. Journal of Personality Assessment, 92(5), 449-57. doi:10.1080/00223891.2010.497426

Deniz, M. E., Ozer, E., \& Isik, E. (2013). Trait Emotional Intelligence Questionnaire -Short Form: Validity and reliability studies. Egitim ve Bilim, 38(169), 407-19.

Engin, M. (2017). Analysis of Students' Online Learning Readiness based on their emotional intelligence level. Universal Journal of Educational Research, 5(12A), 32-40.

Ersoy, E., \& Uysal, R. (2018). Opinions of School Psychological Counselors on Giftedness and Gifted Students' Education. American Journal of Qualitative Research, 2(2), 120-142.

Eurostat - Immigration in the EU. (2017b). Retrieved December 1, 2018 from www.ec.europa.eu/dgs/homeaffairs/e-library/ docs/infographics/immigration/migration-in-eu-infographic_en.pdf

Eurostat Statistics Explained. (2017a, January). First time asylum applicants in the EU-28 by citizenship. Retrieved from www.ec.europa.eu/eurostat/statistics-explained/index.php /File:First_time_asylum_ applicants_in_the_EU-28_by_citizenship,_Q3_2016_\%E2\%80\% 93_Q3_2017.png.

Eurpean Council. (2019). A new strategic agenda 2019-2024. Retrieved May 27, 2019 from https://www.consilium. europa.eu/en/press/press-releases/2019/06/20/a-new-strategic-agenda-2019$2024 /$

Friedman, M. J. (2013). Finalizing PTSD in DSM-5: Getting here from there and where to go next (PDF). Journal of Traumatic Stress, 26, 548-56. doi:10.1002/jts.21840

Friedman, M. J. (2018). PTSD history and overview. Retrieved January 17, 2019 from www.ptsd.va.gov /professional/ptsd-overview/ptsd-overview.asp

Ghazali, S.R. (2014). Investigating The relationship between Post-Traumatic Stress Disorder (PTSD) symptoms and emotional intelligence among adolescent refugees from the Middle East. ASEAN Journal of Psychiatry, 15(2), 220-24.

Hall-Clark, B. N., Kaczkurkin, A. N., Asnaani, A., Zhong, J., Peterson, A. L., Yarvis, J. S., ... Foa, E.B. (2017). Ethnoracial differences in PTSD symptoms and trauma-related cognitions in treatment-seeking active duty military personnel for PTSD. Psychological Trauma: Theory, Research, Practice, and Policy, 9(6), 741-74. doi:10.1037/tra0000242

Haller, H., Cramer, H., Lauche, R., and Dobos, G. (2015). Somatoform disorders and medically unexplained symptoms in primary care: A systematic review and meta-analysis of prevalence. Dtsch. Ärztebl. Int. 112, 279-287. doi:10.3238/arztebl.2015.0279

Hašto, J., Švančarová, O., Suško, J., \& Gyén, D. (2011). Posttraumatická stresová porucha - prevalencia u psychiatrických hospitalizovaných pacientov. Psychiatria pre prax, 11(4), 161-64.

Helliwell, J., Layard, R., \& Sachs, J. (2018). World happiness report 2018. New York: Sustainable Development Solutions Network.

Hendl, J. (2009). Přehled statistických metod. Praha: Portál.

Hinton, D. E., \& Lewis-Fernandez, R. (2011). The cross-cultural validity of Post-Traumatic Stress Disorder: Implications for DSM-5. Depression and Anxiety, 28(9), 783-801. doi:10.1002/da.20753

Kaliská, L., \& Nábělková, E. (2015). Psychometrické vlastnosti a slovenské normy Dotazníkov črtovej emocionálnej inteligencie pre deti, adolescentov a dospelých. Banská Bystrica: Belianum.

Kaliská, L., \& Sollárová, E. (2017). Construct and incremental validity of the Slovak version of trait emotional intelligence questionnaire - adolescent's short form. Psychology Applications \& Developments : Advances in Psychology and Psychological Trends. III. Lisabon : InScience Press.

Kaliská, L., Nábělková, E., \& Salbot, V. (2015). Dotazníky črtovej emocionálnej inteligencie TEIQueSF/TEIQue-CSF: Manuál k skráteným formám. Banská Bystrica: Belianum.

Kessler, R. C., Aquilar-Gaxiola, S., Alonso, J., Benjet, C., Bromet, E. J., Cardoso, G., ... Koenen, K.C. (2017). Trauma and PTSD in the WHO World Mental Health Surveys. Eur J Psychotraumatol, 8(5), 13531383. doi:10.1080/20008198.2017.1353383 
Lanzara, R., Scipioni, M. \& Conti, C. (2019). A clinical-psychological perspective on somatization among immigrants: A systematic review. Front. Psychol. 9, 2792. doi:10.3389/fpsyg.2018.02792

Martskvishvili, K. (2015). Relationship between emotional intelligence and post-traumatic stress. Retrieved January 12, 2018 from https://ge.boell.org/sites/default/files/uploads/ 2015/11/khatuna.pdf

Medzinárodná klasifikácia chorôb MKCH-10-SK-2016. (2017). Medzinárodná klasifikácia chorôb s účinnost’ou 01.01.2017. [International Classification of Diseases, ICD-10].

Medzinárodná organizácia pre migráciu (International Organization for Migration, IOM). (2018). Slovenská republika. [cit. 2018-1-12]. www.iom.sk/sk/migracia, Accessed 17 January 2018.

Migračná politika Slovenskej republiky s výhl’adom do roku 2020 [Migration policy in the Slovak Republic with a View up to the Year 2020 accepted by the Slovak Republic Government in 2011], prijatá uznesením vlády Slovenskej republiky č. 574 z 31. augusta 2011.

Mikolajczak, M., Luminet, O., Leroy, C., \& Roy. E. (2007). Psychometric properties of the Trait Emotional Intelligence Questionnaire: Factor structure, reliability, construct, and incremental Validity in a Frenchspeaking population. Journal of Personality Assessment, 88 (3), 338-353.

Nábělková, E. (2012). Psychometrické vlastnosti Dotazníka črtovej emocionálnej inteligencie pre dospelých (TEIQue). Psychologica Universitas Comeniana - zborník FF UK. Bratislava: Stimul.

Palmer, B., Donaldson, C., \& Stough, C. (2008). Emotional intelligence and life satisfaction. In P. A G. Lang (Ed.), Counterpoints, emotional intelligence: Perspectives on Educational and Positive Psychology, 336, 131-43. [cit. 2018-2-28]. Retrieved from www.jstor.org/stable/42980146

Perruchoud, R. (2004). Glossary on Migration. Geneva: International Organization for Migration (IOM).

Petrides, K. V. (2009). Trait Emotional Intelligence Questionnaire (TEIQue). Technical Manual. London: London Psychometric Laboratory.

Petrides, K. V., Pérez-González, J. C., \& Furnham, A. (2007). On the criterion and incremental validity of trait emotional intelligence. Cognition and Emotion, 21(1), 26-55.

Petrides, K. V., Pita, R., \& Kokkinaki, F. (2007). The location of trait emotional intelligence in personality factor space. British Journal of Psychology, 98, 273-289.

Práško, J., Hájek, T., \& Preiss, M. (2002). Postraumatická stresová porucha a jak se jí bránit. Praha: Maxdorf.

Salbot, V., \& Slušná, E. (2015). Črtová emocionálna inteligencia vo vzt’ahu k životnej spokojnosti. In K. Millová, A. Slezáčková, P. Humpolíček, \& M. Svoboda (Eds.), Sociálne procesy a osobnost'. Brno: Masarykova univerzita.

Shiroma, P. R., and Alarcon, R. D. (2011). Time for healing: Somatization among chronically mentally ill immigrants. J. Cult. Divers. 18, 3-7.

Štatistický úrad SR - Stav obyvatel'stva v SR k 31. 12. (2018). (5 450 421) [Slovak Republic Statistics Office / Office of Labour, Social Affairs and Family in Slovakia, 2018]. Retrieved January 17, 2019 from https://www.susr.sk/wps/portal?urile=wcm:path:/obsah-sk-inf-akt/informativnespravy/vsetky/53574f49-236a-4825-9db7-126a97ca429a

Stough, C., Saklofske, D. H., \& Parker, J. D. A. (2009). Assessing emotional intelligence: Theory, research, and applications. London: Springer Science + Business media.

Ulutas, I. (2017). Psicometric properties of the Trait Emotional Intelligence Questionnaire (TEIQe) in Turkish. Curr Psychol, Springer Science+Business Media, LLC. doi:10.1007/s12144-017-9647-z

Vinayak, S., Safariolyaei, N., \& Pragu. V. (2016). Emotional intelligence and empathy as predictors of PTSD among intimate partner emotionally abused men. IJAHMS, 2(2), 52-60.

Vymětal, Š. (2009). Krízová komunikace a komunikace rizika. Praha: Grada Publishing, a.s.

Weathers, F. W., Litz, B. T., Keane, T. M., Palmieri, P. A., Marx, B. P., \& Schnurr, P. P. (2013). The PTSD checklist for DSM-5 (PCL-5). Scale available from the National Center for PTSD Retrieved January 17, 2017 from www.ptsd.va.gov

\section{Funding details.}

This work was supported by the VEGA Agency under Grant 1/0654/17.

\section{Biographical note.}

Lada Kaliská is an assistant professor of educational, school and counseling psychology at Matej Bel University in Banská Bystrica, Slovakia. She had participated at several research projects of moral intelligence, social intelligence and successful intelligence of R.J. Sternberg (as a principal research investigator /20102011/). Since 2010, she has been involved in the research projects aimed at trait emotional intelligence construct verification and adaptation of diagnostic instruments of trait EI in the Slovak conditions. Since 2017, she is a principal investigator of a project (VEGA 1/0654/17) aimed at emotional intelligence construct complex and profound verification in the international context.

Bilal Akbey is a Turk living in Slovakia for more than four years. He is a Turkish language teacher teaching at Matej Bel University. He finished his PhD. study from Psychology at Faculty of Psychology 
PanEuropean University in Bratislava, Slovakia. His study and also this article were inspired by his personal experiences with PTSD of the Turks living in Turkey and the migrants, Turks, in Slovakia, and wondering of the influences that support the emotional well-being of his compatriots in Slovakia. Nowadays, he feels half as a Turk and half as a Slovak man. 